\title{
TOKOH PEMIKIR MERCANTILISME DAN PENGARUHNYA TERHADAP PERUBAHAN SOSIAL MASYARAKAT
}

\begin{abstract}
Nur Hikmah (90100118014)
Pemikiran ekonomi merkantilis adalah kebijakan yang sangat melindungi industri, di dalam negeri, tetapi mendorong persaingan, sementara ada pembatasan terkendali pada kegiatan perdagangan luar negeri, kebijakan kependudukan yang mendorong keluarga dengan banyak anak, kegiatan industri di negara dengan tingkat upah yang rendah. (Pujiati, 2011)
\end{abstract}

Dari sudut pandang sejarah, menurut Robert (2008) merkantilisme adalah yang tertua dan dapat dianggap sebagai teori penting dalam ekonomi internasional, karena berkontribusi pada gagasan sistem "koersif" sebagai dasar dari semua negara-bangsa. Perkembangan merkantilisme klasik dikaitkan dengan kebangkitan negara-bangsa modern di Eropa pada abad 15-18. Kekayaan dan kekuasaan dianggap sebagai dua bagian yang tidak terpisahkan dari proses membangun bangsa dan negara yang sejahtera dan aman. Dalam arti, kekayaan dan kekuasaan berputar dalam lingkaran setan sehingga tujuan akhirnya adalah menghasilkan kekayaan, yang pada gilirannya meningkatkan kekuatan. (Erna, 2017)

Merkantilisme selalu melihat logam mulia sebagai peluang kekayaan, Ketika koin masih digunakan sebagai uang resmi dunia, ada beberapa yang melihat peluang untuk memanfaatkan kepemilikan emas dan perak mereka. Ini adalah bank, orang yang meminjamkan uang dan tukang emas atau toko perhiasan. Mereka melihat bahwa bukti meminjam, menyimpan atau menyimpan emas dan perak di tempatnya juga dapat diterima di pasar. (Emily, 2017)

\section{Perkembangan Pemikiran Tokoh "Merkantilisme"}

1) Jean Bodin (1530-1596)

Jean Bodin, (1530-1596) lahir di Angers, Prancis dan meninggal

pada bulan Juni 1596, di Laon. Bodin adalah seorang filsuf politik Prancis yang mengekspos prinsip-prinsip pemerintahan yang sangat berpengaruh dan stabil di Eropa abad pertengahan 
untuk memberikan solusi kepada negara-negara yang menggunakan sistem terpusat. Dalam bukunya yang berjudul "Reponse Aux Paradoxes de Malestroit (1568) "60, dikatakan Bodin, kenaikan harga barang secara umum disebabkan oleh 5 faktor, yaitu:

a) Peningkatan logam mulia seperti perak dan emas.

b) Praktek monopoli yang dilakukan oleh dunia swasta serta peran Negara.

c) Jumlah barang dalam negeri menjadi langka karena sebagian produksinya diekspor.

d) Gaya hidup mewah di kalangan bangsawan dan raja. (5) Nilai koin mengalami penurunan karena kandungan karat yang terkandung di dalamnya telah dikurangi atau dimainkan.

\section{2) Thomas Mun (1571 - 1641)}

Thomas Mun adalah seorang pedagang kaya dari Inggris yang banyak menulis tentang perdagangan luar negeri. Mun adalah anggota dari kelompok ekonomi pedagang Inggris, (abad ke-17) lebih dikenal sebagai Encyclophedia Britanica yang paling terkenal dan paling dihormati dari "Mercantilis". Kelompok ini menyarankan agar Inggris menggunakan surplus perdagangan untuk memakmurkan negara secara ekonomi. Dalam bukunya yang pertama yaitu A Discourse of Trade, From England unto The East-Indies (1621), Mun tidaklah dianggap terlalu merkantilis. Ia menyatakan bahwa "negara akan menjadi makmur dengan cara yang sama seperti yang ditempuh oleh sebuah keluarga, dengan penghematan dan menyimpan uang lebih banyak ketimbang yang mereka keluarkan. Demikian juga, negara dan keluarga akan miskin jika terlalu banyak menghamburkan uang.

\section{3) Jean Baptiste Colbert (1619 - 1683)}

Jean Baptiste Colbert lahir di Reims, Prancis pada tanggal 29 Agustus 1619 dan meninggal pada tanggal 6 September 1683. Colbert bukanlah seorang ekonom, melainkan seorang pejabat negara Prancis dengan posisi sebagai menteri kepala ekonomi dan keuangan dalam pemerintahan Raja Louis XIV. Colbert menjamin hak monopoli yang diberikan kepada perusahaan guna mendorong munculnya perusahaan baru, terutama untuk perdagangan antar negara. Ini merangsang penemuan baru dan membangun industri 
percontohan. Ia juga mendorong perkembangan ilmu pengetahuan dengan mendirikan akademi, perpustakaan dan memberikan subsidi kepada setiap sektor ekonomi.

\section{4) Sir William Petty (1623 - 1687) Sir}

Sir William Petty lahir pada 26 Mei 1623 dan meninggal pada 16 Desember 1687. Dia adalah seorang ekonom, ilmuwan dan filsuf Inggris, anggota Parlemen Inggris dan juga anggota piagam Royal Society. Menurutnya suatu negara perlu mengatur jumlah uang yang beredar, karena menurutnya uang dibutuhkan dalam jumlah yang memadai, jika lebih atau kurang dari yang dibutuhkan dapat menimbulkan masalah. Harga uang merupakan bunga modal, sehingga semakin besar jumlah uang beredar maka semakin rendah bunga modal maka akan mendorong kegiatan usaha.(Faruq \& Mulyanto, 2017) 


\section{DAFTAR PUSTAKA}

Faruq, U. Al, \& Mulyanto, E. (2017). Sejarah Teori-Teori Ekonomi (Issue 1).

Pujiati, A. (2011). Menuju Pemikiran Ekonomi Ideal: Tinjauan Filosofis Dan Empiris. Fokus Ekonomi, 10(2), 114-125.

Utama, I., Ekonomi, D., Global, P., Merkantilisme, A., \& Liberalisme, D. (n.d.). Ideologi Utama Dalam Ekonomi Politik Global Antara Merkantilisme Dan Liberalisme.

Saidy, Emily. (2017). Uang dalam Tinjauan Islam. Laa Maisyir. 6(2), 25-40 